Original Paper

\title{
Penguatan Sains dan Teknologi Bagi Generasi Muda di Kota Mataram
}

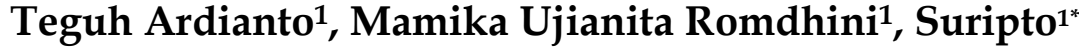 \\ ${ }^{1}$ Program Studi Biologi FMIPA Universitas Mataram, Indonesia
}

DOI: 10.29303/jpmpi.v2i1.363

Sitasi: Ardianto, T., Romdhini, M., \& Suripto, S. (2020). Penguatan Sains dan Teknologi Bagi Generasi Muda di Kota Mataram. Jurnal Pengabdian Magister Pendidikan IPA, 3(1). doi:https://doi.org/10.29303/jpmpi.v2i1.363

*Corresponding Author:

Suripto, Program Studi Biologi

FMIPA Universitas Mataram,

Indonesia;

Email: suriptobio@unram.ac.id

\begin{abstract}
Abstrak: Majunya suatu negara dalam bidang iptek sangat tergantung dari keseimbangan dalam kemajuan ilmu dasar dan ilmu terapan, sehingga kurangnya minat generasi muda, dalam hal ini siswa untuk melanjutkan studi ke perguruantinggi, misalnya Fakultas MIPA Universitas Mataram bisa menghambat kemajuan suatu negara dalam bidang iptek. Pemahaman dasar-dasar matematika sebagai alat analisis dan lemahnya konsep dasar sains meyebabkan rendahnya minat siswa untuk melanjutkan studi di bidang sains dan teknologi. Mengatasi kesulitan belajar siswa antara lain dapat dilakukan dengan cara memberikan pemantapan kembali (review) konsep-konsep yang dianggap cukup fundamental sains, dengan metode yang lebih variatif. Secara umum penguatas sains dan teknologi kepada generasi muda di Kota Mataram, dalam hal ini siswa SMA kelas XII SMA melalui pemberian wawasan sains dan teknologi dapat menumbuhkan minat siswa untuk mempelajari sains dan teknolgi. Minat siswa untuk melanjutkan studi di bidang sains dan teknologi juga meningkat.
\end{abstract}

Kata kunci: Generasi Muda; Minat; Penguatan Sains dan Teknologi

\section{Pendahuluan}

Salah satu peranan universitas adalah mempersiapkan lulusannya dengan keterampilan yang memadai untuk tugas masa depan mereka. Keterampilan yang harus dimiliki peserta didik pada abad 21 adalah berpikir kritis, pemecahan masalah, kreatif, inovatif, dan menguasai teknologi. Untuk itu, kampus menjadi salah satu tempat yang harus dapat menyediakan sarana dan fasilitas, lingkungan pembelajaran yang kondusif, agar dapat menumbuhkembangkan keterampilan tersebut. Hal ini telah menyebabkan perubahan dalam pembelajaran, khususnya matematika, baik di tingkat SD, sekolah menengah maupun perguruan tinggi (Baswedan, 2019).

Siswa SMA atau sederajat yang ingin melanjutkan studinya ke perguruan tinggi kerap kebingungan dalam memilih bidang minatnya. Sebagian ingin mengambil ilmuilmu terapan (rekayasa/engineering), sebagian ingin mengambil ilmu-ilmu dasar (MIPA). Sifat utama dari ilmu rekayasa adalah instan efeknya dirasakan masyarakat, sementara ilmu dasar pada umumnya tidak bisa instan dirasakan oleh masyarakat. Ilmu-ilmu dasar sering membutuhkan waktu sangat lama untuk bias dirasakan masyarakat awam, bahkan bias memakan waktu berabad-abad. Akibat sifat instan ini maka minat siswa untuk 
melanjutkan studinya ke ilmu dasar jauh lebih sedikit daripada yang ingin melanjutkan studinya ke ilmu terapan.

Program-program studi dibawah MIPA tergolong sebagai ilmu hilir, dimana ilmu-ilmu yang dihasilkan banyak digunakan program studi ilmu rekayasa untuk menciptakan teknologi-teknologi baru. Oleh karena itu ilmu MIPA dikatakan hulu dari ilmu pengetahuan, sementara ilmu rekayasa dikatakan hilir dari ilmu pengetahuan. Majunya suatu negara dalam bidang iptek sangat tergantung dari keseimbangan dalam kemajuan ilmu dasar dan ilmu terapan, sehingga kurangnya minat siswa untuk melanjutkan studi ke Fakultas MIPA bias menghambat kemajuan suatu negara dalam bidang iptek. Apabila Indonesia hanya menghasilkan dokter-dokter hebat tanpa punya ahli Kimia atau ahli Biologi yang seimbang hebatnya, maka dokter-dokter tadi akan sangat tergantung pada penemuan obatobat dari ahli Kimia dan ahli Biologi asing.

Salah satu cara untuk menghindari ketimpangan dari peminat ilmu-ilmu dasar di lingkungan Universitas Mataram secara khussu, dan Indonesia secara umum adalah dengan memberikan gambaran tentang Fakultas MIPA dan memberikan motivasi siswa SMA untuk menjadi saintis. Oleh karena itu, Kegiatan Pengabdian Kepada Masyarakat Mandiri dari Fakultas MIPA akan mengadakan suatu kegiatan sosialisasi Fakultas MIPA Universitas Mataram dan motivasi menjadi saintis.

Berdasarkan analisis situasi dan kajian pustaka, maka masalah yang dikaji dalam studi ini dirumuskan sebagai berikut: Bagaimana membangun penguatan sains dan teknologi bagi generasi muda di Kota Mataram? Berdasarkan rumusan masalah tersebut, maka studi ini utamanya bertujuan untuk memberikan kontribusi penguatan sains dan teknologi bagi generasi muda di Kota Mataram.

\section{Metode Pelaksanaan}

Kegiatan pengabdian penguatan sains dan teknologi bagi generasi muda di Kota Mataram ini merupakan wadah bagi siswa untuk melakukan serangkaian upaya yaitu kegiatan refleksi, penemuan masalah, pemecahan masalah melalui beragam strategi untuk meningkatkan ketrampilan dalam mengelola pola pikir ilmiah khususnya yang dibutuhkan dalam dunia kerja. Oleh karena itu pengabdian masyarakat yang di kemas dalam kegiatan pembimbingan kepada para siswa dilakukan. Aspek siswa yang dibahas adalah membangun keterampilan yang harus dimiliki peserta didik pada abad 21 adalah berpikir kritis, pemecahan masalah, kreatif, inovatif, dan menguasai teknologi, serta penerapan Matematika dan Sains di dunia kerja. Generasi muda yang menjadi khalayak sasaran studi ini adalah siswa kelas XII SMA Negeri 5 Mataram.

Sesuai dengan kerangka pemecahan masalah tersebut di atas, maka pelaksanaan kegiatan ini dilakukan dalam tiga tahap, yaitu tahap persiapan, tahap pelaksanaan dan tahap evaluasi dan pelaporan.

Tahap persiapan adalah penyusunan materi sains dan teknologi, yang meliputi tujuan pembelajaran sains dan teknologi yang mengimplementasikan Taksonomy of Bloom dalam tiga aspek, yaitu kognitif, afektif dan sikomotor atau keterampilan. Out come dari pembelaran ini diharapkan siswa memiliki kemampuan berfikir kritis, keterampilan pemecahan masalah, kreatif dan inovatif melalui penguasaan sains dan teknologi yang dimilikinya.

Tahap pelaksanaan dilakukan melalui metode klasik tatap muka dan diskusi, yang ditunjang dengan perangkat pembelajaran berupa silabus, LCD, sound system, dan model-model pembelaran sains dan teknologi.

Tahap evaluasi dan pelaporan dilakukan untuk menghasilkan resume dan rekomendasi-rekomendasi untuk upaya lebih lanjut penguatan sains dan teknologi bagi generasi muda Indonesia pada umumnya dan 
siswa SLTA di Kota Mataram pada khususnya..

\section{Hasil dan Pembahasan}

\section{Pencapaian Tujuan}

Hasil kegiatan studi ini memperoleh respon dan apresaiasi yang positif dari peserta maupun guru atau pamong pendamping dan pengurus sekolah. Hal ini ditunjukkan dengan sambutan Kepala Sekolah serta harapan dan keinginan yang ingin dicapai dalam kegiatan pengabdian ini. Dari diskusi dengan kepala dan pengurus sekolah diharapkan dari kegiatan ini siswa lebih mengenal ilmu-ilmu dan prospek pekerjaan terutama ilmu sains dan teknologi inovatif sehungga siswa dapat mempunyai wawasan dan pilihan-pilihan dalam menentukan bidang ilmu dalam studi lanjutnya.

Dalam kegiatan dengan sasaran kegiatan pengabdian ini yaitu generasi muda juga diperoleh respon dan apresiasi yang positif. Hal ini ditunjukkan dengan antusiasnya peserta dalam menyimak maupun mengajukan pertanyaan-pertanyaan dalam pemaparan dan diskusi materi ilmu sains dan teknologi inovatif. Dalam pemaparan materi, nara sumber memberikan pemahaman mengenai begitu luasnya ruang lingkup yang dapat dipelajari dalam sains dan teknologi dan peluang kerja yang ada setelah lulus kuliah nanti. Hal ini untuk mengeleminir anggapan bahwa belajar sains dan teknologi sarat dengan rurmus-umus yang rumit Dalam pemaparan disertakan juga nara sumber dari student ambassador, yaitu mahasiswa Fakultas MIPA Unram yang diharapkan dapat menyakinkan peserta bahwa belajar sains itu meyenangkan.

\section{Pencapaian Sasaran}

Sasaran peserta kegiatan Pengabdian Kepada Masyarakat dalam bentuk ceramah inteaktif dan testimoni dengan student ambassador adalah siswa-siswi SMA kelas XII. Peserta kegiatan ini adalah siswa-siswi SMAN
5 Mataram didampingi guru pendamping. Dengan demikian secara umum kegiatan ini menacapai sasaran seperti yang diharapkan.

Pencapaian manfaat dari kegiatan Pengabdian Kepada Masyarakat ini dapat terukur dari tingkat kepuasan peserta kegiatan. Hasil evaluasi Tim Pengabdian Kepada Masyarakat menunjukkan bahwa 70\% peserta menyatakana cukup puas dengan kegiatan ini dan perserta menyatakan memperoleh informasi baru dan pencerahan dari materi-mataeri yang disampaikan.

\section{Analisis Hasil Kegiatan}

Beberapa faktor pengambat yang ditemukan pada kegiatan penguatan $\mathrm{s}$ ins dan tekmologi bagi generasi muda, khususnya siswa kelas XII SMA di Mataram, yaitu 1) kurangnya dasar-dasar matematika yang digunakan sebagai alat analisis dalam mempelajari ilmu sains dan teknologi; 2) lemahnya pemahaman konsep dasar dalam dalam mempelajari ilmu sains dan teknologi; dan 3) dengan kurangnya dasar-dasar analisis matematika dan lemahnya pemahaman konsep sains meyebabkan pembelajaran siswa kurang sistematis dan mengganggap bahwa pembelajaran ilmu sains hanya merupakan rumus-rumus saja. Namun demikian, ditemukan juga adanya factor pendorong, yaitu 1) adanya keinginan kuat siswa-siswi peserta untuk melanjutkan studi terutama di bidang sains dan teknologi; serta 2) terbukanya wawasan kesadaran peserta sebagai generasi muda untuk menguasai sains dan teknologi dalam rangka kemajuan bangasa Indoensia.

Sains dan teknologi memeran peranan yang penting dalam kemajuan suatu bangsa. Siapapun yang ingin menguasai dunia, maka harus mampu menguasai sains dan teknologi. Dua hal ini (sains dan teknologi) merupakan dua hal yang menentukan pertarungan dalam kompetisi global. Oleh karena itu, sebagai bangsa yang terus membangun, maka tidak ada pilihan lain bagi kita kecuali mengembangkan dan mentransformasi ilmu pengetahuan dan teknologi hingga tahapan 
implentasi yang benar-benar dapat memperteguh martabat bangsa ini dalam pergaulan dunia yang makin kompetitif. Penguasaan sains dapat menjadi salah satu tolok ukur kemajuan pembangunan di suatu negara.

Menurut Hamengkubuono (2019), sistem pendidikan kita selama ini cenderung mencetak intelektual-intelektual yang tidak kreatif. Seharusnya, mahasiswa diberi kebebasan untuk mengembangkan kemampuan intelektual dan kreativitas mereka. "Kreativias siswa atau mahasisiwa dapat tumbuh dan berkembang dengan baik, apabila selama di sekolah atau kampus diberi kebebasan serta tantangan untuk berkreasi, berekplorasi, bereksperimen dalam tindakantindakan yang nyata. Dengan demikian teori dan dunia realita akan terakumulasi dalam semangat keingintahuan mahasiswa" ungkapnya.

Hamid (2019) menekankan pentingnya jiwa kemandirian sebagai karakter yang harus dimiliki generasi muda Indonesia. Dasron menilai, karakter berjiwa mandiri haruslah tumbuh dan menjadi jalan hidup generasi muda yang merupakan penerus estafet pembangunan bangsa.

Pada zaman sekarang, teknologi sangatlah berpengaruh dalam setiap kegiatan. Dalam setiap bidang dalam kehidupan. Baik dalam bidang pertanian, pertambangan, perikanan dan terlebih dalam bidang ekonomi dan industri. Dalam bidang ekonomi, teknologi berperan dalam produksi, pengemasan dan pemasaran. Dalam sektor industri, teknologi juga sangat berperan dalam produksi produk, seperti mesin-mesin produksi. Oleh sebab itu, para pekerja wajib dan harus memahami tentang pemanfaatan teknologi dalam proses pengerjaan produksi produk. Para pekerja yang kurang dalam pemahaman teknologi akan tertinggal bahkan tidak akan dipekerjakan karena dalam setiap proses menggunakan bantuan teknologi. Untuk mempersiapkan generasi yang mampu memanfaatkan teknologi dengan baik perlu diadakan pendidikan teknologi dan informasi.
Pembelajaran TIK yang sangat bermanfaat dalam kehidupan.

Pendidikan teknologi, informasi dan komunikasi (TIK) merupakan salah satu cara yang dilaksanakan pemerintah untuk menunjang pengetahuan generasi muda (milenial). Sebagai contoh, di SMA Unggulan CT ARSA Foundation telah memasukkan pelajaran TIK dalam penentuan kelulusan nilai raport. Maka setiap siswa-siswi baik yang suka maupun tidak suka harus dan wajib mempelajari TIK. Dengan demikian, para siswa setidaknya sudah mengetahui dan memiliki dasar dalam mempelajari teknologi. Karena sudah memiliki dasar, para alumni dari SMA Unggulan CT ARSA Foundation saat di universitas yang mereka masuki memiliki kemampuan yang lebih dari mahasiswa lain yang belum pernah belajar tentang TIK. Mereka pun lebih mudah untuk mengerjakan tugas TIK dari dosen di universitas tersebut.

Dan ketika siswa SMA Unggulan CT ARSA Foundation yang ingin langsung bekerja dapat melihat peluang dan kesempatan yang lebih dalam bidang teknologi, informasi dan komunikasi dibanding dengan siswa SMA lain yang tidak dan belum belajar TIK dan dapat menghasilkan hasil yang lebih juga. Siswa SMA Unggulan CT ARSA Foundation tersebut dapat membuka peluang pekerjaan terhadap generasi milenial lainnya.

Dikarenakan hal tersebut pemerintah wajib dan harus memasukkan pelajaran teknologi, informasi dan komunikasi dalam kurikulum pelajaran. Di dalam buku tentang Kecerdasan Ganda (Multiple Intelligences), Daniel Goleman menjelaskan kepada kita bahwa kecerdasan emosional dan sosial dalam kehidupan diperlukan $80 \%$, sementara kecerdasan intelektual hanyalah $20 \%$ saja. Dalam hal inilah maka pendidikan karakter diperlukan untuk membangun kehidupan yang lebih baik dan beradab, bukan kehidupan yang justru dipenuhi dengan perilaku biadab. Maka terpikirlah oleh para cerdik pandai tentang apa yang dikenal 
dengan pendidikan karakter (character education).

Karena pelajaran teknologi, informasi dan komunikasi sangat berperan penting dalam kehidupan baik disekolah maupun dilingkungan masyarakat. Siswa- siswi merupakan generasi milenial penerus generasi sekarang. Maka perlu diadakan perubahan pendidikan dan perubahan pola pikir para guru dan siswa-siswi agar menghasilkan masa depan yang dapat memanfaatkan teknologi, informasi dan komunikasi.

Ketika pemerintah dapat memanfaatkan teknologi, informasi dan komunikasi dengan baik maka setiap kegiatan akan terlaksana dengan cepat, praktis dan mudah. Ketika setiap pekerjaan dapat terlaksana dengan baik maka hasil dari kegiatan tersebut dapat dimanfaatkan oleh banyak masyarakat. Contohnya, Negara Republik Indonesia. Pada saat generasi milenial Indonesia dapat memanfaatkan teknologi, informasi dan komunikasi akan membuat negara Indonesia yang saat ini sedang berkembang menjadi negara Indonesia yang maju seperti negara Jepang, Korea Selatan dan Amerika Serikat. Negara-negara maju tersebut sudah sangat mampu memanfaatkan teknologi, informasi dan komunikasi dalam produksi, pengemasan dan pemasaran. Pemanfaatan teknologi, informasi dan komunikasi dalam proses produksi berupa alat- alat dan mesin-mesin yang canggih dapat mempermudah para produsen dalam menghasilkan seangkaian produk yang sangat berguna dalam kehidupan.

Contoh pemanfaatan teknologi, informasi dan komunikasi dalam proses pengemasan berupa kemasan yang dapat melindungi produk dari gangguan dari luar dan dapat juga dimanfaatkan untuk menambah jangka waktu pemanfaatan produk tersebut. Gangguan dari luar berupa bau, kerusakan dan lain-lainnya. Contoh pemanfaatan teknologi, informasi dan komunikasi dalam proses pemasaran berupa penjualan produk-produk melalui internet (online) dan pemasaran di dunia maya.
Generasi muda atau yang sekarang lebih dikenal sebagai generasi milenial adalah generasi kreatif dan pekerja keras yang diberikan akses terhadap informasi melimpah. Mereka berinteraksi dengan cara berbeda dengan generasi pendahulunya. Mereka perlu diberikan saluran komunikasi dan wahana untuk mengalirkan tradisi dan budaya termasuk dalam penelitian dan pengembangan. Kemenristek Imbau Magang dan Wirausaha jadi Bagian Pendidikan Tinggi Dimyati juga menjelaskan bahwa sangat penting menanamkan, memupuk, dan mengembangkan minat generasi milenial terhadap ilmu pengetahuan dan teknologi melalui kegiatan penelitian dan pengembangan. Ia mengharapkan dari sini pada saatnya akan membuahkan hasil berupa kemajuan daya saing bangsa dan negara Indonesia.

Pendidikan generasi muda adalah kunci keberhasilan masa depan sebuah bangsa. Sebuah negara dapat menjadi negara yang maju apabila memilki generasi muda yang cerdas dan mampu bertindak. Penguasaan sains dan teknologi merupakan salah satu kunci untuk membawa Indonesia keluar dari krisis yang dihadapi, menuju peradaban yang lebih maju.

Pentingnya mendidik anak, kita sebagai orangtua harus memahami bagaimana menjadi orangtua yang baik. Parenting harus dipelajari dan dipraktekan, hanya karena kita pernah menjadi anak-anak bukan berarti kita bisa mendidik anak-anak dengan baik, hanya karena kita bisa menyetir kendaraan bukan berarti kita bisa mendidik orang menjadi pengendara yang baik. Itu dua hal yang berbeda, kerena itu mari kita pelajari bagaimana cara mendidik anak dengan baik sesuai jamannya.

Lebih lanjut Anies mengatakan bahwa di masa depan, meritrokrasi memiliki peranan yang sangat besar. Kita sudah tidak bisa lagi mengandalkan unsur, pertemanan, $\square$ untuk membuat jalur agar anak kita memiliki masa depan. Anak kita sukses bila kita membekali dengan ilmu pengetahuan dan kompetensi yang baik. ,Menguasai ilmu pengetahuan itu 
mutlak, yang tidak kalah penting untuk menyongsong masa depan yang lebih baik adalah menguasai bahasa asing, terutama bahasa Inggris.

\section{Kesimpulan}

Pemahaman dasar-dasar matematika sebagai alat analisis dan lemahnya konsep dasar sains meyebabkan rendahnya minat siswa untuk melanjutkan studi di bidang sains dan teknologi. Mengatasi kesulitan belajar siswa antara lain dapat dilakukan dengan cara memberikan pemantapan kembali (review) konsep-konsep yang dianggap cukup fundamental sains, dengan metode yang lebih variatif. Secara umum kepada peserta siswasiswi kelas XII SMA memberikan wawasan dan menumbuhkan minat untuk mempelajari saisn dan teknolgi. Minat sisww juga meningkat untuk melanjutkan studi di bidang sasins dan teknologi.

Melihat antusiasme para siswa-siswi peserta dalam mengikuti kegiatan manfaatnya yang sangat besar terutama dalam meningkatkan tingkat pemahaman dan minat siswa dalam mempelajari sains dan teknologi, maka diharapkan kegiatan ini memiliki keberlanjutan di masa-masa mendatang.

\section{Daftar Pustaka}

Hamengkubuono, S. H. (2019). Peranan Sains Dan Teknologi Dalam Kemajuan Bangsa. https://edukasi.kompas.com . 13 Nov. 2019

Baswedan, A. (2019). Generasi muda, Ilmu Pengetahuan, Seni dan Teknologi. https://www.ristekdikti.go.id. 13 Nov. 2019

Hamid, D. (2019). Peranan Sains Dan Teknologi Dalam Membangun Karakter Generasi Muda. www.umy.ac.id > mendikbud-sainsdan-teknologi. 13 Nov. 2019 